\title{
Dynamic Stabilization of the Spine: A New Classification System
}

\section{Omurganın Dinamik Stabilizasyonu: Yeni Bir Sınıflandırma Yöntemi}

\begin{abstract}
Fusion surgeries are still the gold standard in the treatment of the degenerative spine. Spinal fusion has some problems, however. Adjacent segment disease, donor place ailment, and the morbidity of the surgery has emerged as important problems over the years. As a consequence of such complications after fusion, the search for an alternative treatment for the degenerative spine widened. While trying to maintain the motion in the joint, dynamic stabilization aims to remove the pain by distributing the weight between anterior and posterior elements of the spine. Various new devices have now been developed for the dynamic stabilization of the spine. In this report, the dynamic stabilization devices of the spine are classified anew and, the authors explain briefly the historical evolution process, specialties, indications and contraindications of these dynamic stabilization devices.
\end{abstract}

KEYWORDS: Dynamic stabilization, Classification, Lumbar spine, Disc prosthesis, Facet replacement, Interspinous device

\section{ÖZ}

Dejeneratif omurganın tedavisinde füzyon cerrahisi hala altın standarttır. Bununla beraber spinal füzyon diğer bazı problemlere sahiptir. Yıllar içinde komşu segment hastalığı, donor yeri rahatsızlıkları ve cerrahinin getirdiği morbidite önemli problemler olarak ortaya çıktı. Füzyondan sonra görülen bu tür komplikasyonların bir sonucu olarak degeneratif omurga için alternatif tedavi arayışları yaygınlaştı. Dinamik stabilizasyon eklemdeki hareketi sürdürmeye çalışırken, omurganın ön ve arka elemanları arasındaki yükü paylaşarak ağrıyı gidermeyi amaçlar. Bugünlerde, omurganın dinamik stabilizasyonu için değişik yeni cihazlar geliştirildi. Omurganın dinamik stabilizasyon cihazları yeni bir şekilde sınıflandırıldı ve dinamik stabilizasyon cihazlarının tarihsel gelişim süreci, özellikleri, endikasyonu ve kontraendikasyonları açıllandı.

ANAHTAR SÖZCÜKLER: Dinamik stabilizasyon, Sınıflandırma, Lomber omurga, Disk protezi, Faset protezi, İnterspinoz cihaz

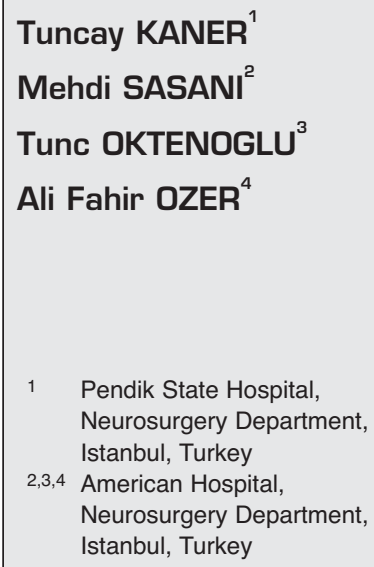

Received : 24.08.2009

Accepted : 10.12.2009

Correspondence address:

Ali Fahir OZER

American Hospital, Neurosurgery

Department, Guzelbahce Sk. No: 20

34365 Nisantasi - Istanbul, Turkey

Phone : +90 2123112000

Fax : : +90 2123112724

E-mail : alifahirozer@gmail.com 


\section{INTRODUCTION}

Since Mixter and Barr performed the first lumbar discectomy surgery in 1934, it has been understood that a ruptured intervertebral disc can cause low back pain with radiation down to the leg by forming a herniation that pressures the nerve roots $(5,47,48)$. Although the initial procedure was hailed as a landmark success, postoperative failures and negative surgical results began to emerge with growing frequency. Later, numerous scientific clinical studies revealed that negative results or failure in the range of $20-30 \%$ were possible in the treatment of lumbar disc herniations $(10,12,21,46,47)$.

In 1982, it was claimed that disc degeneration, like herniation, might cause low back pain (40). Relief from pain was observed in patients with low back pain when local anesthesia was applied to degenerative discs. Such observations were supported by continued scientific publications. While some studies sought to determine how the disc degenerations occur and cause pain, others tried to develop various methods for treating the pain that results from a degenerative disc.

There have been two essential advancements that have furthered the understanding of disc-related pain. The first advancement was the introduction of discography as a diagnostic method in the clinic (31). Although discography was initially criticized for not being as sensitive or as fine as myelography, its importance has increased with time, since there is not any better study to reveal the internal structure of the disc. Although the reliability of discography results is rightfully debated, it is still used widely. The second advancement is MRI technology. The data on disc structures, ligament structures and soft tissue structures are priceless in shedding light on lumbar disc pathology. Moreover, the knowledge gained concerning spine mechanics, spine motions, and the emergence of the acute and chronic instability concepts helped us to understand the importance of sustaining spine stability.

Today, it is known that disc degeneration other than herniation also decreases the quality of life by causing chronic low back pain $(40,42,55,62)$. The largest common mistake is treating such pathologies by removal with classical or microdiscectomy techniques, which causes pain as a result of segmental instability $(19,40)$. Such treatments have resulted in serious problems and raised the level of skepticism concerning disc hernia operations among physical therapists and in general society.

Over time, it was revealed that the degree of clinical condition after subtotal lumbar discectomy was closely related with the degree of disc degeneration and the existence of sufficient paravertebral muscle support. If the disc was excessively degenerated, with no muscle support, results were poor. It has been reported in various publications that low back pain sometimes prevails long after subtotal discectomy surgery $(19,28)$. Moreover, patients with a black disc experience back cramps and frequent pain in the lower back. Since performing a discectomy causes deformation in the disc, such a situation may worsen or be easily triggered after lumbar discectomy surgery. A disc's structure suffers serious degeneration if a subtotal discectomy is performed in order to prevent recurrence and as much tissue as possible is taken out. Even if we relieve the patient from radicular pain, discogenic pain or pain resulting from segmental instability may occur $(19,20,28)$. Such negative experiences with subtotal discectomy brought forth the idea of putting something else in place of a removed disc. Cloward proposed interbody fusion after classic discectomy for the first time (13). Although plausible in theory, the "Stop the movement and stop the pain" principal is not easy to achieve in practice. It is difficult to fuse moving systems, and, besides, if posterior affixed bone grafts escape to the canal, important complications may arise. Posterolateral intertransverse fusion gives positive results in young patients, but since bone quality is not as good in elder patients, the pseudoarthrosis rate is very high in the older group $(3,7,14,17)$.

This limitation gave birth to the idea of performing a fusion and leaving the spine motionless. Harrington developed rods and then transpedicular screw fixation systems $(29,56)$. Results were much better than in-situ fusion. Today, in the treatment of low back pain, fusion surgeries are still the gold standard. The problem is still not solved, however.

Spinal fusion has other problems. Adjacent segment disease, donor place ailment, and the morbidity of the surgery have emerged as important problems over the years $(16,23,70)$. Besides, in spite 
of perfect radiological fusion images, patients' improvements were not always equal (8). Since fusion surgeries (where the injured joint is removed to relieve pain) were not solving the problem, perhaps distributing the load away from the deformed segment and maintaining motion was the answer. This was a novel and important opinion when it emerged.

\section{Anterior Dynamic Stabilization}

\section{Anterior Disc Prosthesis}

The idea of placing an anterior dynamic instrument belongs to Fernstrom. In his surgeries, he tried to maintain movement by placing steel balls in the intervertebral space (15). However, since the balls were touching the cartilage end plates at a point, the balls slowly broke the cartilage end plates and burrowed into the intervertebral space. Over time, then, movement ceased. It was an early practical step towards maintaining movement. Laboratory and animal research has yielded hundreds of patents since then, however, the first modern prosthesis, named CHARITE, was designed and used in humans by Katrin Butner Janz (11). Although complications and revisions were very common during initial years, Charite III took its final form and is now widely used clinically. Charite III was certified by the FDA in October of 2004 (27).

At the beginning, a shock absorbent intermediate material was used in the Charite disc. Later, the intermediate was replaced with a polyethylene pillow in order to reduce metal-on-metal friction and to facilitate smooth movement. According to type, rotational movement is allowed, limited, or completely restricted. Today, there are several certified brands in the market available to use. A literature review showed that indications for use can be summarized shortly as: patients between 18-60 ages (optimally below age 50 years) with a single level or two level pain due to symptomatic degenerative disc disease, patients with positive provocative discogram, the absence of facet joint degeneration changes, existence of intervertebral disc height of at least $4 \mathrm{~mm}$, non radicular leg pain or back pain and postlaminectomy syndrome $(6,45)$. It has contraindicated in deformations and spondylolysis in the posterior elements, in shift instabilities, the elderly patients who have osteoporosis, morbid obesity, infection and patients with systemic diseases such as allergy to metal $(6,45)$. Therefore, it has very limited usage. Since it maintains movement, it is recommended for use at L4-5. L5-S1 application showed abnormal physiology $(57,60)$. When it is used within the indications, results are very satisfactory. In new prospective clinical study patients did not show any morbidity, and patient satisfaction was very high (57). The most criticized aspects are the lack of elasticity, or a shock absorbent feature, and the limited application area.

\section{Alternative Nucleus Replacements}

PDN, The Prosthetic Disc Nucleus (PDN-Solo, Raymedica Inc, Minneapolis, MN): It assumes the cushioning function of a normal disc, and concurrently maintains disc height and flexibility. This device consists of a hydrogel pellet surrounded by a polyethylene layer (41). Clinical study results with PDN are badly $(51,58)$. Therefore, nowadays usage of PDN is limited.

NUBAC, Disc Arthroplasty System (Invibio, Greenville, NC, USA): This newly developed device, which will be used for arthroplasty, should maintain or restore the disc height and mechanical function of the disc. This device is a less invasive and nonbridge-burning disc arthroplasty system. There is one study in the literature. This study is preliminary report and according to this study disc height improved but lumbar motion did not improve (2).

DASKOR, Disc Arthroplasty System (Disc dynamics, Inc, Eden Prairie, MN; Investigational status): This is a balloon device filled entirely with an injectable, pressurized polyurethane polymer (66). In a new prospective nonrandomized multicenter study, it was seen that dascor device may be a safe and effective less-invasive surgical option for a patient with degenerative disc disease (1).

\section{Posterior Dynamic Stabilization}

\section{Pedicle Screw/Rod Based Stabilization Devices}

The Graf ligament, designed and named by Henry Graf in 1992, is used firstly in spine stabilization (24). Graf drew wide attention and his concept has since gained popularity $(22,33,34)$. Meanwhile, important technological advances occurred. Graf was against risky surgeries (such as fusion) for the treatment of pain due to instability as a result of degenerative events. He thought such 
surgeries were too dramatic. He advocated that a supporting posterior extension band was good enough in the treatment of such instabilities. Patient series related to the Graf ligament were published constantly. Some were in favor of the procedure $(22,32,34,43,48)$ and some were against it $(4,54)$. However, approaches emerged to deal with encountered troubles such as the loosening of the ligament with time, foraminal narrowing as a result of compression, and flat back (25). The literature is full of examples of recurrent instability as a result of screw loosening in time (33).

Although it was a fine concept, the system had weaknesses and could have been better designed. In fact, after considering the weak points and disadvantages of the Graf ligament, Zimmer developed the Dynesys system $(39,61)$. In Dynesys, artificial ligaments were used, however, a spacer was implemented between pedicular screws so that foraminal compression was avoided. The most important point was to calibrate the tightness of the ligament. The lack of standard implementation and the fluctuation from surgeon to surgeon presented a problem. Overly-tight ligaments behaved just like rigid rods. Dynesys is certified by FDA only for stabilization of spinal segments as an adjunct to fusion in 2004 not as a motion-preserving implant and is widely used by the practitioners who believe in dynamic stabilization all over the world $(33,59,67)$. Just like there are supporters of Dynesys, there also are the ayes $(52,59,67)$.

There are proponents of fusion who claim that Dynesys has no superiority over fusion $(8,26)$. To solve the standardization of ligament tightness problem, the Medtronic medical company tried to standardize the dynamism on rods. They produced the Agile rod, which has fixed flexion, extension, and rotation pace. However, after having predicaments in clinical applications, they took it off the market (65). This attempt at standardizing the rods' movements opened the door for other companies to produce similar rods all over the world. Moreover, rods with flexion and extension abilities against various loadings have been manufactured. Peek and carbon fiber rods are dynamic and are mainly used to compress the bone graft in a fusion (30). More dynamic rods are produced in order to be used with rigid screws within dynamic concept limits (44). However, the ideal dynamic rod has not yet been produced.
The opinion of dynamic stabilization may also provide an advantage over rigid fixation when used as a posterior tension band complements in lumbar fusion surgery (44). According to Wolff's law, the transmission of forces to an intervertebral graft and avoidance of "stress shielding" could potentially increase the rate and likelihood of a successful arthrodesis (18). Increased load transfer through the fusion mass should lead to a more favorable surroundings for fusion (63). This can be achieved with the development and use of flexible devices (63). In order to facilitate fusion, Strempel kept the graft between vertebral bodies under constant pressure by increasing axial loading on spine with the help of an added joint on the screw's neck (68). Although long-term results revealed pseudoarthrosis in some patients, all patients were completely relieved of their pain. He continued using the system without performing fusion. According to the Louis concept, load stabilizes posterior articular columns from behind and the screw head rod locks are placed behind facet joints, which thus provides motion in facet joints. Posterior dynamic stabilization transfers the load through the posterior column and stabilizes the spine almost like a rigid stabilization technique, preserving motion (9). Even though such a system is said to be semirigid, we think that placing a joint on the screw is a stroke of genius. It is recommended to be used in one or two places; otherwise, the system loses its dynamism because of the rigid rod. However, when dynamism of the rod is increased, it can be used in multiple segments; such development would be a huge leap in the field of deformity surgery. In a new prospective clinical study dynamic rod and hinged screw case series results are promising $(35,36,37,38)$. We compared dynamic stabilization to fusion surgery in one level and our results supported dynamic stabilization that is superior to fusion surgery in the treatment of degenerative instabilities (49).

Such developments in posterior transpedicular dynamic systems directed researchers towards more complicated systems. Posterior dynamic systems have more application area than anterior disc prostheses. In order to use anterior disc prosthesis in either cervical or lumbar spine, the ideal indication requires patient age of 20-50, healthy posterior components, and a disc distance not less than $4 \mathrm{~mm}$. Moreover, it is recommended to be used in one or 
two intervertebral spaces $(6,45,57)$. Posterior dynamic systems can be used in all ages, deformity in posterior components does not effect the indication (on the contrary, it removes the deficiency in laminectomy and facetectomy patients), and it is not affected by progressive degeneration of anterior components. With its extensive application area, it is an option for a wide group of patients. For all these reasons, complicated instruments in accordance with the original anatomy are being planned.

The most important advantage of posterior dynamic systems is providing a healthy load transfer to the lower spine in chronic instabilities. That is the reason for pain relief. In reality, there is no harm if the system fuses in time. Patient feels no pain in this process. There is no such thing as absolute motion in every joint for a whole human life. As organisms get older, joint mobility gradually decreases. As a result, there is no need to blame the dynamic system that is adaptive to the movement for decreasing or stopping motion in the joint. In our judgment, the real mistake would be designing an instrument with infinite physiologic movement, assuming a normal functional segment would remain normal in a lifetime. A system with $4^{\circ}$ flexion and extension at an age of 30, while considered to be normal, would not be normal at age of 70; it would be considered to be hypermobile.

\section{Total Facet Replacement System}

The Tops system was the first to be used in clinical trials. TOPS, TFAS and ARFS are a total facet arthroplasty system and differ from the remaining dynamic stabilization devices (65). After removing the facets, flexion, extension, and controlled transverse motion, are provided by a mechanism that is placed on two connection rods over transpedicular placed screws. It was promising at the beginning; however, difficulties in its application and the lack of published successful clinical results have prevented it from becoming widespread. Still, similar systems are being developed for clinical trials (39).

\section{Posterior Interspinous Distractor devices}

The French orthopedist Senegas thought that he could partially improvise a vertebral column and improve patients' clinical view in degenerative spondylolystesis patients by distracting spinal processes and widening the canal. He developed the Wallis system (64). Clinical applications gave successful results. Since it is very easy to apply locally, it became popular all over the world and is widely used. Many similar systems were designed later on. X-Stop is the most widely used interspinous implant (65). This titanium spacer device can be used a minimally invasive approach under local anesthesia; so especially elderly patients with medical comorbidity can consider good candidates for this device (65). Since there is no spinous extremity in S1, it cannot be used in L5-S1. Also, there are no usage indications other than for the lumbar level. An in vivo study with MRI scans showed that the implant widens the spinal canal and the neural foramina (53). Biomechanical studies determined that, while correcting the shift in the vertebral column, interspinous processes reduce and facilitate load transfer by forming a rigid bridge in the back (69). Therefore, it is also used in black disc with pain and after discectomies that show a risk of instability development (69). Possible concerns for this implant are its effects on bone tissue and the possible creation of local osteoporosis in the placement area. It is also effective for a limited time only. It is an ideal solution for the elderly with concomitant medical problems.

The summary of indications and contraindications of dynamic devices are given Table I.

As a result, Dynamic stabilization systems can be categorized as follows:

\section{I) Anterior Dynamic Stabilization}

A. Anterior disc prosthesis (Total Disc Replacements)

$$
\begin{aligned}
& \text { 1. Cervical Disc Replacements (Figure 1A,B,C) } \\
& \text { - Prestige ST (Medtronic, FDA Cleared) } \\
& \text { - Bryan (Medtronic) }
\end{aligned}
$$

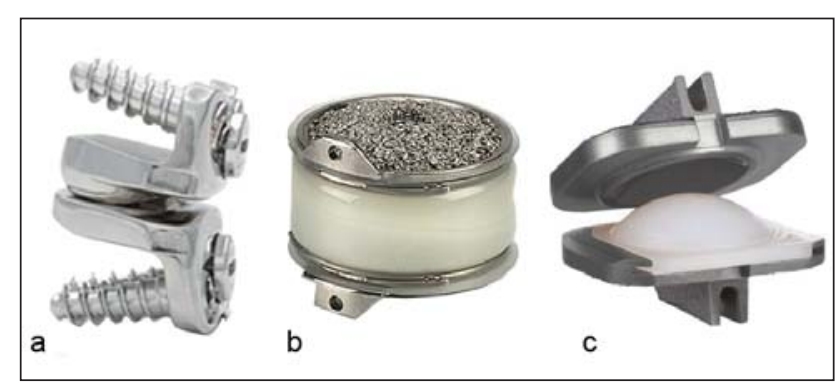

Figure 1: Cervical Disc Replacements: A) Prestige ST, B) Bryan, C) Prodisc-C. 
Table I: Dynamic Stabilization of the Spine: Indications and Contraindications $(6,22,24,33,39,45,48,61,65,68,69)$

\begin{tabular}{|c|c|c|}
\hline Devices & Indications & Contraindications \\
\hline Anterior Disc Prosthesis & $\begin{array}{l}\text { - patients between 18-60 ages (optimally } \\
\text { below age } 50 \text { years) } \\
\text { - } \text { single level or two level } \\
\text { - pain due to symptomatic degenerative } \\
\text { disc disease } \\
\text { - absence of facet joint degeneration } \\
\text { changes } \\
\text { - existence of intervertebral disc height } \\
\text { - } \text { of at least } 4 \text { mm } \\
\text { - ponradicular leg pain or back pain } \\
\text { - patient with positive discogram }\end{array}$ & $\begin{array}{l}\text { - deformations and spondylolysis in the } \\
\text { - } \text { in shift instabilities } \\
\text { - the elderly patients who have } \\
\text { - } \text { osteoporosis } \\
\text { - infection } \\
\text { - patients with systemic diseases such as } \\
\text { allergy to metal }\end{array}$ \\
\hline $\begin{array}{l}\text { Posterior Dynamic } \\
\text { Stabilization Devices }\end{array}$ & $\begin{array}{l}\text { - degenerative spinal instability (disc } \\
\text { degeneration, facet degeneration, } \\
\text { degenerative spondylolisthesis) } \\
\text { - iatrogenic instability following } \\
\text { discectomy / decomp-ressive } \\
\text { laminectomy } \\
\text { - increased anterior load sharing to } \\
\text { augment interbody fusion } \\
\text { - stabilization of a painful adjacent } \\
\text { segment degeneration, adjacent to } \\
\text { fusion } \\
\text { - complement TDR to achieve anterior } \\
\text { disc replacement } \\
\text { - second recurrent of a disc herniation }\end{array}$ & $\begin{array}{l}\text { - overt instabilities due to tumors and } \\
\text { trauma } \\
\text { - infections } \\
\text { - Istmic type spondylolisthesis } \\
\text { - stabilizations extending beyond two } \\
\text { segment }\end{array}$ \\
\hline $\begin{array}{l}\text { Interspinous Distraction } \\
\text { Devices }\end{array}$ & $\begin{array}{l}\text { - central spinal canal stenosis with } \\
\text { neurogenic cladication } \\
\text { - foraminal stenosis with radicular } \\
\text { symtoms } \\
\text { - facet joint disease } \\
\text { - İn one- or two- level stenosis in patients } \\
\text { over } 50 \text { years }\end{array}$ & $\begin{array}{l}\text { - } \text { overt instabilities } \\
\text { - Infections }\end{array}$ \\
\hline
\end{tabular}

- PRODISC-C (Synthes)

- PCM (Cervitech)

- Prestige LP (Medtronic)

- Discover (DePuy Spine)

- Cervicore (Stryker Spine)

2. Lumbar Disc Replacements (Figure 2)

- Charite (DePuy Spine, FDA Cleared)

- ProDisc-L (Synthes, FDA Cleared)

- Maverick (Medtronic)

- FlexiCore (Stryker Spine/Spine core)

- Regain (Biomet/EBI)

- TrueDisc PL (Disc Motion)

- Kineflex Lumbar Disc (Spinal Motion)

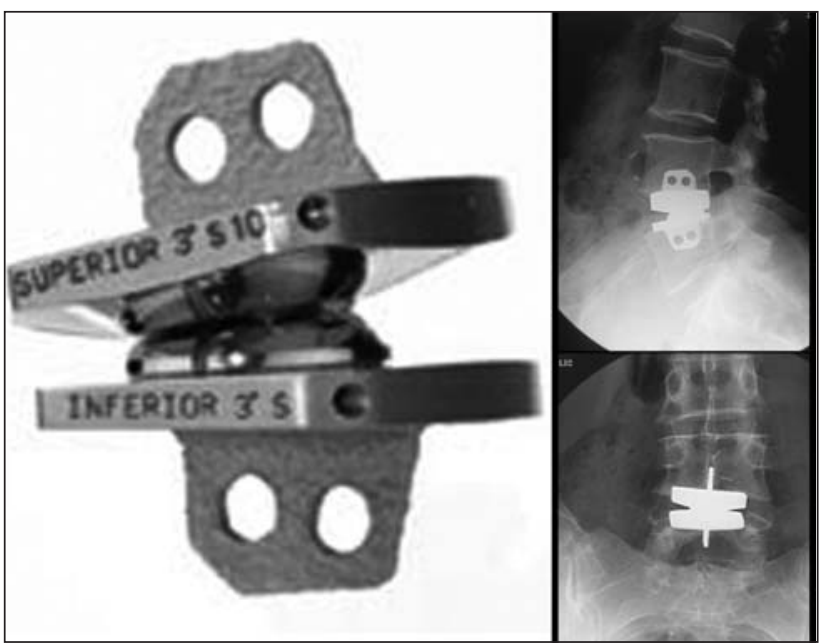

Figure 2: Maverick Lumbar Disc Replacement. 
B. Nucleous Pulposus Alternatives (Figure $3 A, B, C, D)$

- PDN : (PDN-Solo, Raymedica, LLC)

- Nubac: (Invibio, Greenville, NC, USA)

- Daskor: (Disc dynamics, Inc, Eden Prairie, Minn)

- Neudisc: (Replication Medical Inc, New Brunswick, NJ)

C. Nucleous Pulposus Supports 'Cultured cell reinjection' (Figure $4 A, B$ )

- Biodisc (Cryolife, Inc, Kennesaw, GA)

- NuCore IDN (Spine Wave Inc, Shelton, CT)

- Gelifex (Gelifex, Inc, Philadelphia, PA)

\section{II) Posterior Dynamic Stabilization}

A. Posterior transpedicular stabilization (Figure $5 A, B, C, D, E, F)$

\section{i. Pedicle screw-based system}

1. Dynamic rod-rigid screw
a. Rod artificial ligament
- Graf System (Surgigraft)
- Dynesys (Zimmer spine Inc., Warsaw, IN)

b. Rod dynamic metal

i. Talin Rod (Medikon-Algoritma, Istanbul-Turkey)

ii. Scient'X Isobar (Scient'x, S.A.)

iii. Accuflex (Globus Medical Inc., Audubon, PA)

iv. Transition Stabilization system (Globus Medical Inc., Audubon, PA)

v. Bioflex (Biospine Corp., Seoul, Korea)

vi. CD Horizon Agile (Medtronic Sofamor Danek, Memphis, TN)

$\underline{6 \mathrm{~A}, \mathrm{~B}, \mathrm{C}, \mathrm{D}, \mathrm{E})}$

2- Dynamic Rod-Dynamic Screw (Figure

vii.COSMIC (Ulrich GmBH \& Co. KG, Ulm, Germany) or SAFINAZ (Medikon,Turkey) (9,68) hinged transpedicular screws applied with any one of aforementioned dynamic rods $7 \mathrm{~A}, \mathrm{~B})$

ii. Total Facet Replacement Devices (Figure

- TOPS (Total Posterior arthroplasty System, Impliant Spine, Princeton, NJ)

- TFAS (Total Facet Arthroplasty System, Archus Orthopedics, Inc, Redmond, WA)

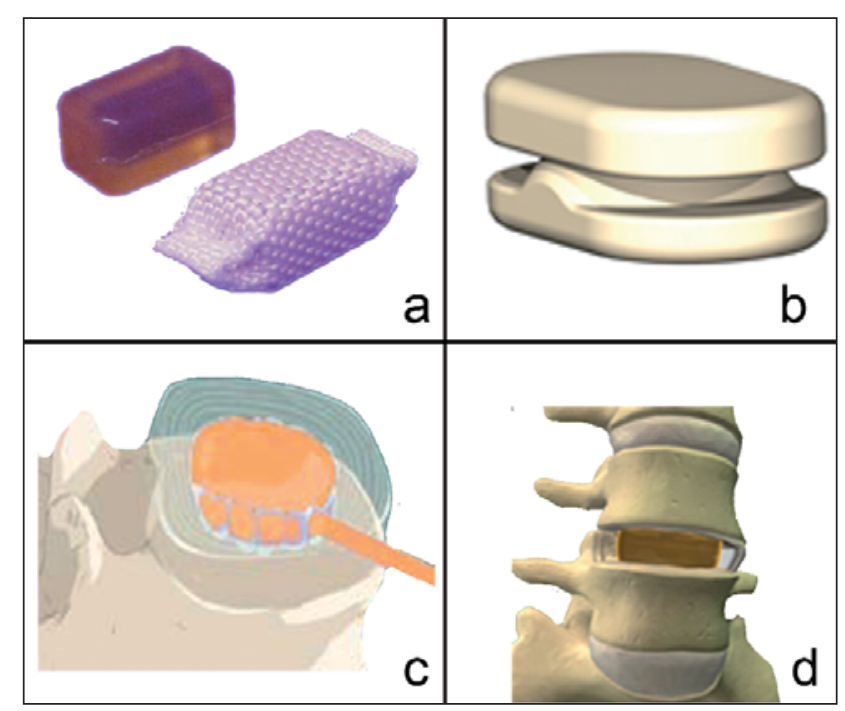

Figure 3: Nucleous Pulposus Alternatives: A) PDN, B) Nubac, C) Daskor, D) Neudisc.

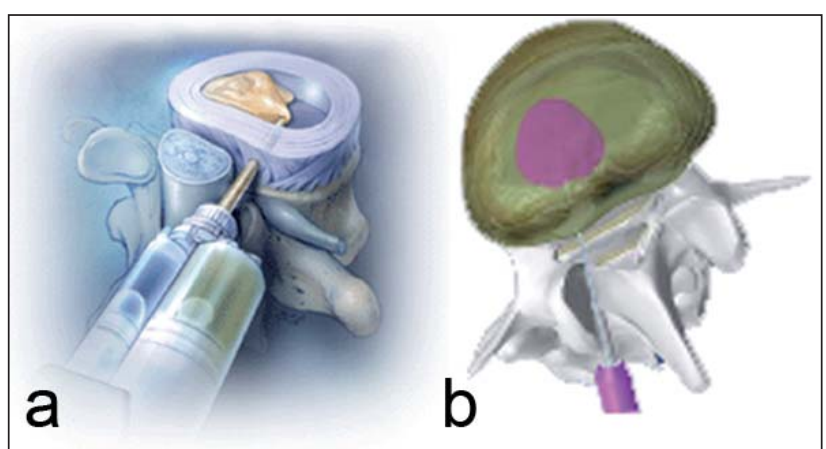

Figure 4: Nucleous Pulposus Supports: A) Biodisc, B) NuCore IDN.

- ARFS (Anatomic Facet Replacement System, Facet Solutions Inc, Logan, UT)

- STABILIMAX NZ (Applied Spine Technologies Inc, New Haven, CT)

B. Posterior Interspinous Stabilization (Figure $8 A, B, C)$

- DIAM (Medtronic Sofamor Danec, Memphis, TN)

- Wallis System (Abbott Spine, Inc., Austin, TX)

- X-stop interspinous process decompression device (Kyphon, Inc., Sunnyvale, CA)

- CoFlex (Paradigm Spine LLC., New York, NY)

- Flexus (Globus Medical Inc., Audubon, PA) 


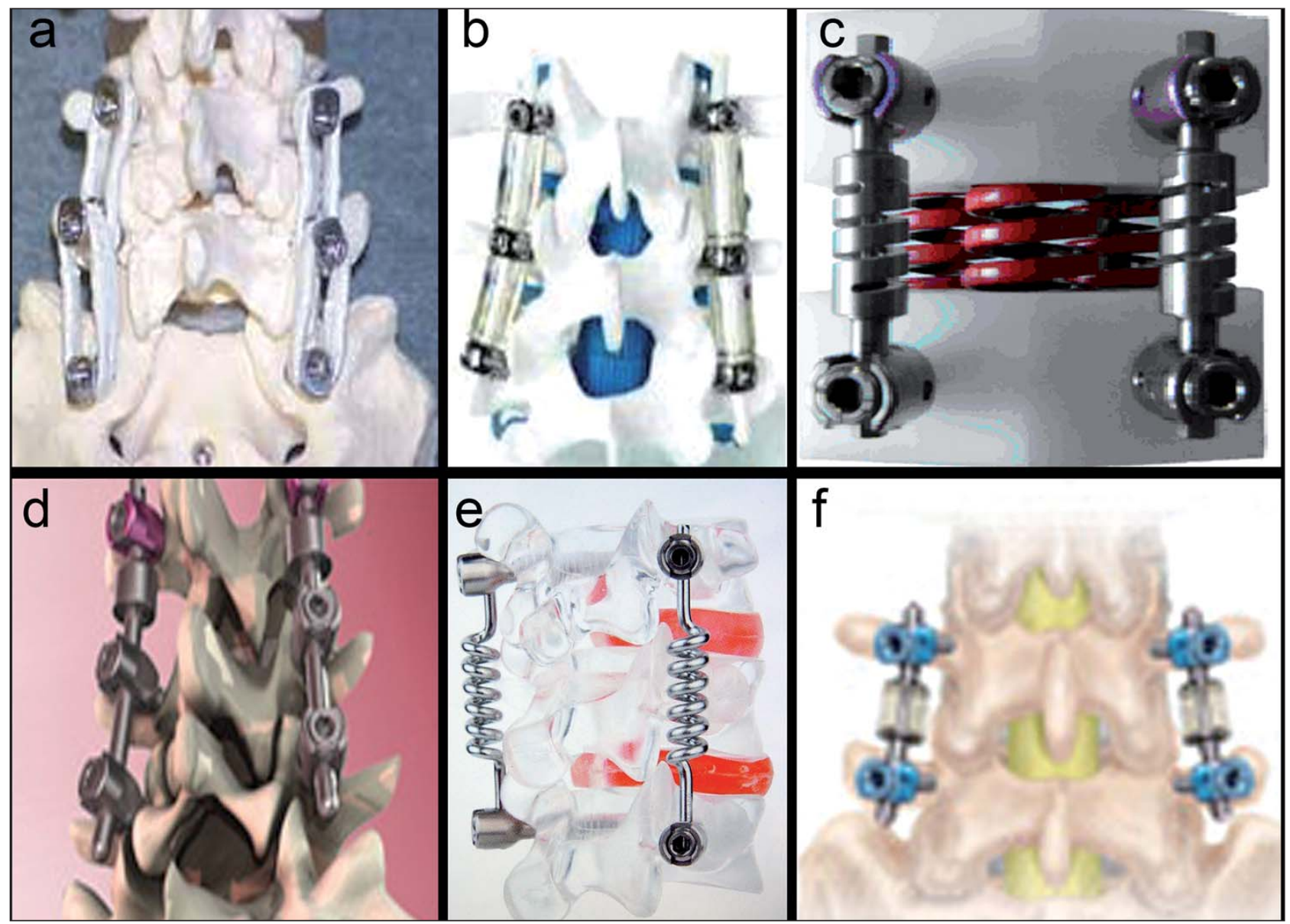

Figure 5: Posterior transpedicular stabilization: A) Graf system, B) Dynesys, C) Talin rod, D) Scient'X Isobar, E) Bioflex, F) CD horizon Agile.

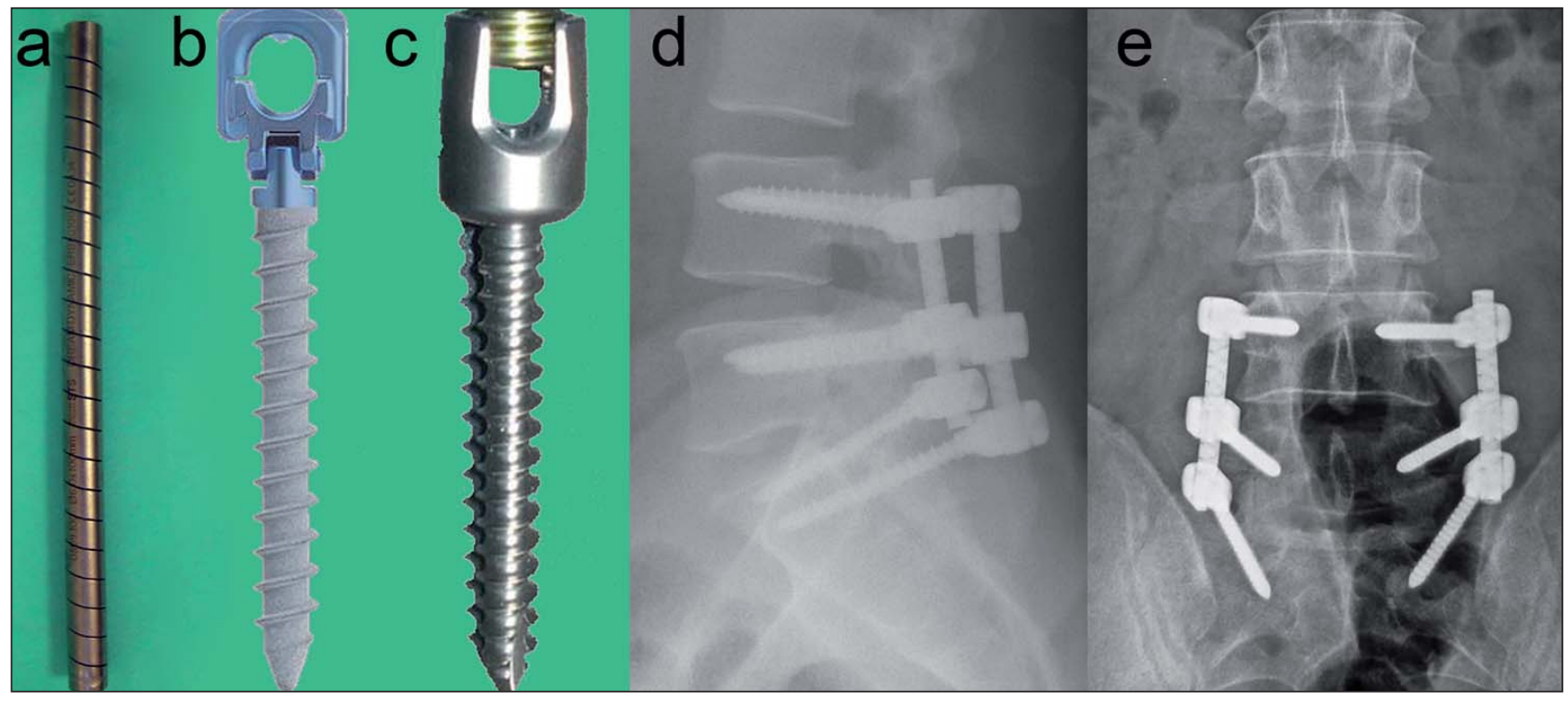

Figure 6: Dynamic Rod-Dynamic Screw: A) Dynamic rod, B) Cosmic screw, C) Safinaz screw, D) lateral X-ray, E) AP X-ray. 


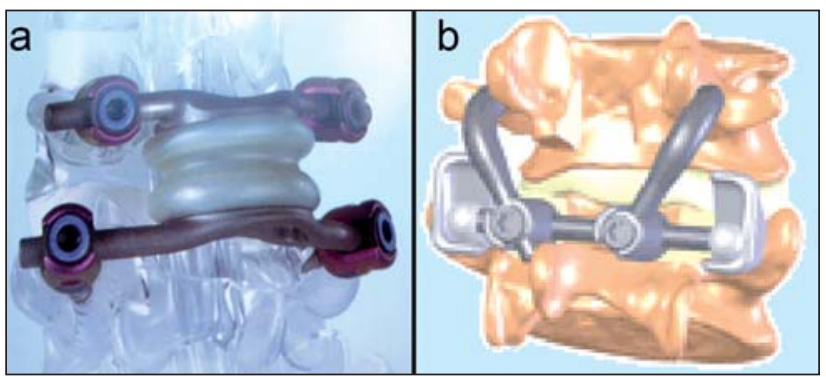

Figure 7: Total Facet Replacement Devices: A) TOPS, B) TFAS.

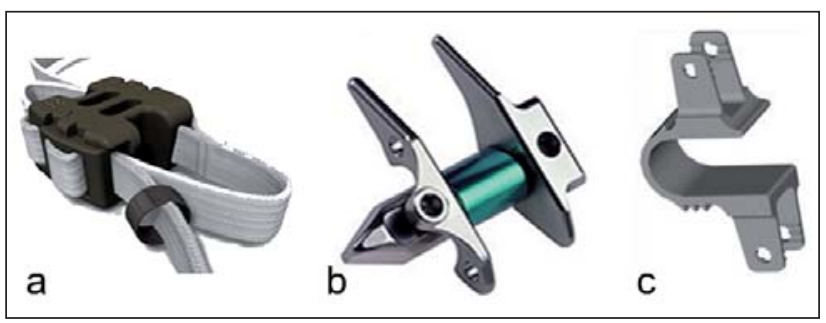

Figure 8: Posterior Interspinous Stabilization: A) Wallis system, B) X-Stop, C) Coflex.

- Superion Spacer (VertiFlex Inc., San Clamente, CA)

- In-Space Interspinous Distraction Device (Synthes, West Chester, PA)

\section{CONCLUSION}

Today, various dynamic stabilization devices have been produced but there is a need for biomechanical and clinical studies to show positive results. We believe that the future of dynamic stabilization devices is encouraging and, that this classification will explain the other classifications and new studies in the future.

\section{REFERENCES}

1. Ahrens M, Tsantrizos A, Donkerstloot $P$, Martens $F$, Lauweryns P, Le Huec JC, Mozsko S, Fekete Z, Sherman J, Yuan HA, Halm H: Nucleus replacement with the dascor disc arthroplasty device. Spine 34 (13):1376-1384, 2009

2. Alpízar-Aguirre A, Mireles-Cano JN, Rosales-Olivares M, Miramontes-Martínez V, Reyes-Sánchez A: Clinical and radiological follow-up of nubac disc prosthesis. Preliminary report. Cir Cir 76 (4):311-315, 2008

3. Anderson T, Christensen FB, Hansen ES, Bünger C: Pain five years after instrumented and non-instrumented posterolateral lumbar spinal fusion. Eur Spine J 12: 393-399, 2003

4. Askar Z, Wardlaw D, Muthukumar, Smith F, Kader T, Gibson S: Correlation between inter-vertebral disc morphology and the results in patients undergoing Graf ligament stabilization. Eur Spine J 13: 714-718, 2004

5. Barker FG: The Massachusetts General Hospital. Early history and neurosurgery to 1939. J Neurosurg 79: 948-959, 1998
6. Bertagnoli R, Kumar S: Indications for full prosthetic disc arthroplasty: A correlation of clinical ourcome against a variety of indications. Euro Spine J 11:131-136, 2002

7. Blumenthal S, Gill K: Complications of the Wiltse pedicle Screw Fixation System. Spine 18: 1867-1871, 1993

8. Bothmann M, Kast E, Boldt GJ, Oberle J: Dynesys fixation for lumbar spine degeneration. Neurosurg Rev 31:189-196, 2008

9. Bozkuş H, Senoğlu M, Baek S, Sawa AG, Ozer AF, Sonntag VK, Crawford NR: Dynamic lumbar pedicle screw-rod stabilization: in vitro biomechanical comparison with standard rigid pedicle screw-rod stabilization. J Neurosurg Spine 12(2):183-9, 2010

10. Burton CV, Kirkaldy-Willis WH, Yong-Hing K, Heithoff KB: Causes of failure of surgery on the lumbar spine. Clin Orthop 157: 191-199,1981

11. Buttner-Janz K, Schellnack K, Zippel H. Biomechanics of the SB Charite lumbar intervertebral disc endoprosthesis. Int Orthop 13:173-176, 1989

12. Caldwell AB, Chasc C: Diagnosis and treatment of personality factors in chronic low back pain. Clin orthop 129: 141-149, 1977

13. Cloward RB: The treatment of ruptured lumbar intervertebral discs by vertebral body fusion. I. Indications, operative technique, after care. J Neurosurg 10:154-68,1953

14. DePalma AF, Rothman RH: The nature of pseudoartrosis. Clin Orthop 59: 113-118, 1968

15. Fernström V: Arthroplasty with intercorporal endoprosthesis in herniated disc and in painful disc. Acta Chir Scand 357:154159, 1966

16. Fritzel P, Hagg O, Wessberg P, Nordwall A: Swedish Lumbar Spine Study Group: 2001 Volvo Award Winner in Clinical studies: Lumbar fusion versus nonsurgical treatment for chronic low back pain. Spine 26:2521-2534, 2001

17. Fritzell P, Hagg O, Wessberg P, Nordwall A: Swedish Lumbar Spine Study Group: Chronic low back pain and fusion: a comparison of three surgical techniques: a prospective multicenter randomised study from Swedish lumbar spine study group. Spine 27: 1131-41, 2002

18. Frost HM: A 2003 update of bone physiology and Wolff's law for clinicians. Angle Orthod 74:3-15, 2004

19. Frymoyer JW: Segmental Instability. In Frymoyer JW (ed): The Adult Spine. New York: Raven Press,1991: 1873-1891

20. Frymoyer JW, Selby DK: Segmental instability: Rationale for treatment. Spine 10:280, 1985

21. Frymoyer JW, Hanley EN, Howe J, Kuhlmann D, Matteri RE: A comparison of radiographic findings in fusion and nonfusion patients, ten or more years following lumbar disc surgery. Spine 4: 435-440, 1979

22. Gardner A, Pande KC: Graf ligamentoplasty: a 7-year followup. Euro Spine J 11: 157-163, 2002

23. Gibson JN, Grant JC, Waddel G: The Cochrane rewiev of surgery for lumbar disc prolapse and degenerative lumbar spondylosis. Spine 24:1820-1832, 1999

24. Graf H: Lumbar instability. Surgical treatment without fusion. Rachis. 412: 123-137, 1992

25. Grevitt MP, Gardner AD, Spilsbury J, Shackleford IM, Baskerville R, Pursell LM, Hassaan A, Mulholland RC: The Graf stabilization system: Early results in 50 patients. Eur Spine J 4 (3):169-175, 1995 
26. Grob D, Benini A, Junge A, Mannion AF: Clinical experience with the dynesis semirigid fixation system for the lumbar spine. Surgical and Patient-oriented outcome in 50 cases after an average of 2 years. Spine 30:324-331, 2005

27. Guyer RD, McAfee PC, hochschuler SH, Blumenthal SL, Fedder IL, Ohnmeiss DD, Cunningham BW: Prospective randomized study of the Charite artificial disc: Data from two investigational centers. Spine J 4: 252S-259S, 2004

28. Hanley EN, Philips ED, Kostuik JP: Who should be fused? In Frymoyer JW (ed): The Adult Spine. New York: Raven Press, 1991: 1893-1917

29. Harrington PR: The history and development of Harrington instrumentation. Clin Orthop 93:110-2, 1973

30. Highsmith JM, Tumialan LM, Rodts GE: Flexible rods and the case for dynamic stabilization. Neurosurg focus 22 (1):E11, 2007

31. Holt EP Jr: The question of lumbar discography. J Bone Joint Surg Am 50:720-726, 1968

32. Kanayama M, Hashimoto T, Shigenobu K, Harada M, Oha F, Ohkoshi Y, Tada H, Yamamoto K, Yamane S: Adjacentsegment morbidity after Graf ligamentoplasty compared with posterolateral lumbar fusion. J Neurosurg 95:5-10, 2001

33. Kanayama M, Hashimoto T, Shigenobu K, Togawa D, Oha F: A minimum 10-year follow-up of posterior dynamic stabilization using graf artificial ligament . Spine 32:19921996, 2007

34. Kanayama M, Hashimoto T, Shigenobu K: Rationale, biomechanics and surgical indications for graf ligamentoplasty. Orthop Clinic North Am 36:373-377, 2005

35. Kaner T, Dalbayrak S, Oktenoglu T, Sasani M, Aydin AL, Özer AF: Comparison of posterior dynamic transpedicular stabilization and posterior rigid transpedicular stabilization with fusion after decompression in the treatment of degenerative spondylolisthesis: a minimum two-year followup. Orthopedics (in press)

36. Kaner T, Sasani M, Oktenoglu T, Aydin AL, Özer AF: Minimum two-year follow-up of cases with recurrent disc herniation treated with microdiscectomy and posterior dynamic transpedicular stabilisation. The Open Orthopedics 4:120-125, 2010.

37. Kaner T, Sasani M, Oktenoglu T, Cosar M, Özer AF: Clinical outcomes after posterior dynamic transpedicular stabilization with limited lumbar discectomy: Carragee system classification of lumbar disc herniations. SAS journal (in press).

38. Kaner T, Sasani M, Oktenoglu T, Cosar M, Ozer AF: Utilizing dynamic rods with dynamic screws in the surgical treatment of chronic instability: A prospective clinical study. Turk Neurosurg.19(4):319-326, 2009.

39. Khoueir P, Kim KA, Wang MY: Classification of posterior dynamic stabilization devices. Neurosurg Focus 22: E3, 2007

40. Kirkaldy-Willis WH, Farfan HF: Instability of the lumbar spine. Clin Orthop 165: 110-123, 1982

41. Klara PM, Ray CD: Artificial nucleus replacement: clinical experience. Spine 27:1374-1377, 2002

42. Kuslich SD, Ulstrom CL, Michael CJ: The tissue origin of low back pain and sciatica: A report of pain response to tissue stimulation during operations on the lumbar spine using local anesthesia. Ortop Clin North Am 22:181-187, 1991
43. Madam S, Boeree NR: Outcome of the Graf ligamentoplasty procedure compared with anterior lumbar interbody fusion with the Hartshill horse shoe cage. Eur Spine J 12:361-368, 2003

44. Mandigo CE, Sampath P, Kaiser MG: Posterior dynamic stabilization of the lumbar spine: Pedicle based stabilization with the accuflex rod system. Neurosurgical focus 22 (1): E9, 2007

45. McAfee PC: The indications for lumbar and cervical disc replacement. Spine Journal. 4 (6): 177-181,2004

46. Mixter WJ, Ayer JB: Herniation or rupture of the intervertebral disc into the spinal canal. N Engl J Med 213: 385-393, 1935

47. Mixter WJ, Barr JS: Rupture of the intervertebral disc with involvement of the spinal canal. N Eng J Med 211: 210215,1934

48. Onda A, Otani K, Konno S, Kikuchi S: Mid-term and longterm follow-up data after placement of the graf stabilization system for lumbar degenerative disorders. J Neurosurg Spine 5:26-32, 2006

49. Ozer AF, Crawford NR, Sasani M, Oktenoglu T, Bozkus H, Kaner T, Aydin S. Dynamic lumbar pedicle screw-rod stabilization: two year follow-up and comparison with fusion. The Open Orthopedics 4, 137-141, 2010

50. Parisien RC, Ball PA: William Jason Mixter (18801958).Ushering in the 'dynasty of the disc'. Spine 23: 23632366, 1998

51. Pimenta L: PDN at 5 years follow-up, In: Spine Arthroplasty society; May 9-13; Montreal, Quebec, Canada; 2006: 82, 2006

52. Putzier M, Schneider SV, Funk JF, Tohtz SW, Perka C: The surgical treatment of the lumbar disc prolapse. Nucleotomy with additional transpedicular dynamic stabilization versus nucleotomy alone. Spine 30: E109-114, 2005

53. Richards JC, Majumdar S, Lindsey DP, Beaupre GS, Yerby SA: The treatment mechanism of an interspinous process implant for lumbar neurogenic intermittent claudication. Spine 30 (7): 744-749, 2005

54. Rigby MC, Selmon GP, Foy MA, Fogg AJ: Graf ligament stabilization: mid-to long term follow-up. Eur Spine J 10:234236, 2001

55. Roberts S, Eisenstein SM, Menage J, Evans EH, Ashton IK: Mechanoreceptors in intervertebral discs, morphology, distirubition, and neuropeptides. Spine 20:2645-2652, 1995

56. Roy-Camiile R, Roy-Camille M, Demeulenaere: Osteosynthesis of dorsal, lumbar and lumbosacral spine with metallic plates screwed into vertebral pedicles and articular apophyses. Presse Med 78: 1447-1448, 1970

57. Sasani M, Oktenoğlu T, Tuncay K, Canbulat N, Carilli S, Ozer FA: Total disc replacement in the treatment of lumbar discogenic pain with disc herniation: A prospective clinical study. Turkish Neurosurgery 19 (2):127-134, 2009

58. Sasani M, Aydin AL, Oktenoglu T, Cosar M, Ataker Y, Kaner T, Ozer AF: The combined use of a posterior dynamic transpedicular stabilization system and a prosthetic disc nucleus device in treating lumbar degenerative disc disease with disc herniations. SAS Journal 2 (3): 62-68, 2008

59. Schnake KJ, Schaeren S, Jeanneret B: Dynamic stabilization in addition decompression for lumbar spinal stenosis with degenerative spondylolisthesis. Spine 31:442-449, 2006

60. Schulte TL, Lerner T, Hackenberg L, Liljenqvist U, Bullmann $\mathrm{V}$ : A Acquired spondylolysis after implantation of a lumbar 
ProDisc II prosthesis: Case report and review of the literature. Spine 15: E645-648, 2007

61. Schwarzenbach O, Berlemann U, Stoll TM, Dubois G: Posterior dynamic stabilization systems: Dynesys. Orthop Clin North Am 36:363-372, 2005

62. Schwarzer AC, Aprill CN, Derby R, Fortin J, Kine G, Bogduk $\mathrm{N}$ : The relative contrubutios of the disc and zygapophyseal joint in chronic low back pain. Spine 19: 801-806, 1994

63. Scifert JL, Sairyo K, Goel VK, Grobler LJ, Grosland NM, Spratt KF, Chesmel KD: Stability analysis of an enhanced load sharing posterior fixation device and its equivalent conventional device in a calf spine model. Spine 24 (21): 22062213, 1999

64. Senegas J: Mechanical supplementation by non-rigid fixation in degenerative intervertebral lumbar segments: the Wallis system. Eur Spine J11 (2): 164-169, 2002
65. Sengupta DK: Dynamic stabilization. Spineline 9: 10-18 , 2008.

66. Sieber AN, Kostuik JP: Concepts in nuclear replacement. Spine J 4:322-324, 2004

67. Stoll TM, Dubois G, Schwarzenbach O: The dynamic neutralization system for the spine : A multicenter study of a novel non-fusion system. Eur Spine J 11: 170-178, 2002

68. Von Strempel A, Moosmann D, Stoss C, Martin A: Stabilization of the degenerated lumbar spine in the nonfusion technique with cosmic posterior dynamic system. WSJ 1:40-47,2006

69. Wiseman CM, Lindsey DP, Fredrick AD, Yerby SA: The effect of an interspinous process implant on facet loading during extension. Spine 15:903-907, 2005

70. Younger EM, Chapman MW: Morbidity at bone graft donor sites. J Orthop Trauma 3: 192-195, 1989 